\title{
THE OIL PALM INDUSTRY IN MALAYSIA: THRIVING WITH TRANSFORMATIVE TECHNOLOGIES
}

\author{
KUSHAIRI, A*; SINGH, R* and ONG-ABDULLAH, $M^{*}$
}

\begin{abstract}
Arriving at this milestone after an illustrious century, the growth from an ornamental palm to a multibillion dollar commodity crop in Malaysia has been a remarkable journey for oil palm. From its humble beginnings in Malaya as a monoculture plantation crop in 1917, it has grown to occupy over 5.7 million hectares of land space by 2016, demonstrating the impact the crop has had on the country's economy over the last 100 years. Its importance has led to many initiatives being implemented with a concerted effort to effectively develop and safeguard the posterity of the industry. In treasuring the past, engaging the present and charting the future, this review reflects briefly on the direction the industry has taken to reach this present state. The foresightedness of early players in the industry has helped thrust the industry forward by systematically building a rich resource within the country. As the industry matures, it is only natural for challenges to surface and there is a constant drive to manage public perception and to stay sustainable in order to remain competitive. In this respect, oil palm has followed in the footsteps of other crops in decoding its genome and simultaneously answering some long-standing questions about the biology of the oil palm. Efforts have also been devoted to automate and mechanise the industry as a solution to address the labour supply issue. Midstream and downstream sectors have experienced similar transformations in their operations as well. Essentially, the employment of these so-called transformative technologies which are the essence of the $4^{\text {th }}$ Industrial Revolution are comparatively still at its infancy for this industry. However, as precision agriculture gains prominence and in keeping to Malaysia's 2050 national transformation aspirations, we envisage that these disruptive technologies will be the driver of innovations in all sectors, especially oil palm.
\end{abstract}

Keywords: oil palm, technologies, sustainable, precision, agriculture.

Date received: 18 October 2017; Sent for revision: 19 October 2017; Received in final form: 5 December 2017; Accepted: 7 December 2017.

\section{A BRIEF HISTORY OF THE OIL PALM}

The history of oil palm in South-east Asia can be traced back to the four oil palm seedlings brought from West Africa and planted at the Bogor Botanical Gardens. As sugar and coffee were the

\footnotetext{
Malaysian Palm Oil Board,

6 Persiaran Institusi, Bandar Baru Bangi,

43000 Kajang, Selangor, Malaysia.

E-mail: kushairi@mpob.gov.my
}

prime economic crops then, the off-springs of the four dura (thick shell) palms were thus relegated to a secondary role as ornamental palms planted in the royal town of Deli in Sumatra, Indonesia and hence came to be known as the Deli palms. A Belgian engineer, Adrien Hallet, in Sumatra in 1905, noticed that the descendants of the four Bogor palms produced larger bunches and had better quality fruits than those he observed in Zaire (now known as the Democratic Republic of the Congo). This led to his pioneering efforts in establishing the 
first oil palm plantation in Sumatra in 1911 from these palms. On a trip to Malaysia (then known as Malaya), Hallet met a Frenchman by the name of Henri Fauconnier who later became his friend and business associate. Fauconnier would subsequently go on to establish the first oil palm plantation in Malaya at Tennamaram Estate in Batang Berjuntai (now known as Bestari Jaya), Selangor, based on materials he sourced from Sumatra.

\section{A THRIVING BUSINESS}

Adequate rainfall, sufficient sunshine and optimal soil conditions found in South-east Asia, particularly Malaysia and Indonesia were ideal for the oil palm to thrive. The low genetic diversity of the early planting materials, which were descended from a limited set of original Bogor palms was also an advantage initially, as more uniform planting material were obtained (Rosenquist, 1986). Furthermore, the new geographical setting also meant that the usual pests and diseases that affected oil palm at its centre of origin were also absent, contributing further to the establishment of the crop in the region (Ornelas, 2000). In a relatively short period by 1919,3000 ha were planted with oil palm in Malaya while the acreage in Sumatra doubled that of Malaya. The end of the First World War in 1919 also saw a declining confidence in the rubber industry, which was an impetus for further expansion of area dedicated to oil palm. The pace of new oil palm plantings accelerated, although the Great Depression in the early 1930s and World War Two (1939 to 1945), brought a period of uncertainty to the industry.

The 1960s was the period that oil palm found a firm foothold in Malaysia, partly brought about by the realisation that it was a viable alternative to rubber and Malaysia had to further diversify its economy. The discovery of single gene inheritance of shell by researchers in Congo (Beirnaert and Vanderweyen, 1941) and with it the commercial potential of the hybrid tenera palms was likely a turning point for the industry. The first wave of yield increments realised through the introduction of the higher yielding thin shell hybrid tenera palms to replace the thick shell dura palms in the late 1950s (Davidson, 1993), contributed significantly to the remarkable growth rate of the industry in the 1960s. The tenera palms were also very well suited to the new screw press technology, first introduced in Congo in the 1950s, to extract palm oil (Ornelas, 2000). These innovations have been described as one of modern agriculture's most significant achievements (Syed, 1981). In this period, the Federal Land Development Authority (Felda) also started to aggressively pursue oil palm cultivation among smallholders. As such, it was of little surprise that Malaysia overtook Nigeria as the world's leading producer and exporter of palm oil in 1966 and the industry has not looked back since then. The fact that the acreage dedicated to oil palm cultivation reached 5.7 million hectares in 2016 reveals how its status has grown from being a minor crop in 1917, to one of the most significant contributor to Malaysia's Gross Domestic Product (GDP) currently. This also demonstrates the impact that the crop has had in uplifting the economy and livelihood of Malaysians over the last 100 years.

\section{EVOLVING INTO A VALUABLE RESOURCE}

One of the major issues faced by the industry in Malaysia early on was the lack of genetic diversity of the descendants of the four Bogor palms. To address this, an interesting development took place in the early 1920s. A set of seeds were sent from Eala Botanical Gardens in Congo to Far East. Palm SP540 from this consignment would give rise to the AVROS pisifera, descendants of which were brought to Malaya (now Malaysia) in 1957 (Rao et al., 1999). Subsequently, Oil Palm Genetics Laboratory (OPGL), an amalgamation of three private companies, namely Guthrie, Harrisons \& Crossfields and Dunlop in 1963, played a critical role in bringing in the first batch of germplasm material to Malaysia from Africa, the centre of diversity for oil palm, in order to further broaden the genetic base of the breeding materials (Davidson, 1993). A collaboration between private companies in Malaysia and Africa (namely Nigeria and Cameroon) was forged through the renowned oil palm expert, CWS Hartley, and pollens from selected tenera palms in Africa were used to cross with high performing Malaysian Deli dura palms (Rajanaidu et al., 1986). The resulting progenies were planted at the Ulu Dusun Research Station in Sandakan (now part of DOA Sabah oil palm collection). Following that, in 1973 oil palm breeders at the Malaysian Agriculture Research \& Development Institute (MARDI) started the initiative to search the tropical regions of the world for wild oil palm plants. The first collection was initiated in Nigeria, and subsequently the search for germplasm led breeders to 10 other countries in equatorial Africa. The team also travelled to eight countries in Central and South America to accumulate a collection of the second species of the palm. Over the past four decades, more than 40 missions have been carried out, leading to hundreds of thousands of seeds of guineensis and oleifera being brought into Malaysia. This resource, the world's most comprehensive oil palm germplasm collection, is maintained as a field bank and is being extensively evaluated. A total of 13 new genetic materials (PS series) developed thus far from the germplasm collection is only the 'tip of the iceberg', as many of the biological traits required 
for the industry to meet future challenges (e.g. adaptability to climate change) remain untapped with the collection.

\section{REMAINING COMPETITIVE}

The rapid growth of oil palm cultivation between 1960s and early 2000 was mainly attributed to the Malaysian government's diversification programme as well as from land expansions (Basiron, 2007). The latter are mostly through land conversion from rubber and other agricultural crops to oil palm. The Malaysian oil palm industry recognises the sensitivity and importance of maintaining the biodiversity rich tropical rainforests and as such actively participates in the certification standards by the Roundtable on Sustainable Palm Oil (RSPO; http: / / www.rspo.org). To ensure the whole industry comes on board, a national level sustainable certification standard, the Malaysian Sustainable Palm Oil (MSPO; http://mspo.mpob.gov.my) was also launched, which aims at ensuring that even smalland mid-range cultivators can operate sustainably.

In overcoming the scarcity of arable land, oil palm productivity per unit area (yield) need to be increased (Phalan et al., 2016). Improvement in productivity is deemed possible considering yields recorded so far have been encouraging at every level. In fact, Durand-Gasselin et al. (2011) has suggested up to $60 \%$ increase in genetic gain within 50 years, which is a remarkable achievement for a perennial crop like oil palm. Plantations are already achieving up to $6 \mathrm{tha}^{-1}$, whilst smallholdings are bringing in 3-4 t ha-1 (Murphy, 2014). However, they are still way below the performance observed among elite breeding lines, which can easily reach $13 \mathrm{t} \mathrm{ha}^{-1}$ under good agronomic practices (Sharma et al., 1999). Through sound breeding programmes superior lines are continuously being developed, however their true potential can only be realised with the combination of both biological and management practices in commercial fields.

Development and identification of elite disease resistant lines is equally important in sustaining yields in the long-term. Durand-Gasselin et al., in 2015 described an elegant research exercise involving field observations and nursery trials, which revealed that La Me-based materials appear to be more resistant to Ganoderma. The screening framework for Ganoderma tolerance described above is now being replicated in many parts of the oil palm growing countries, including Malaysia. Similarly, palms resistant to Fusarium wilt (Flood, 2006), a devastating disease in Africa have also been described. Fortunately, Fusarium wilt is not a serious threat in Malaysia. Nevertheless, commercial E. guineensis species (including those sourced from Malaysia), appear to be very susceptible to the Bud
Rot disease in South America (Romero et al., 2017), indicating the importance of remaining vigilant against the spread of this disease in South-east Asia.

\section{EMBRACING THE $4^{\text {th }}$ INDUSTRIAL REVOLUTION}

Malaysia is blessed with rich natural resources particularly in areas such as agriculture, forestry and minerals. Its economic stronghold has always been in the commodities despite the change in the country's economic scenario in the 1980s and 90s towards manufacturing. With the projection of population growth touching 9 billion, agricultural products need to increase by $70 \%$ and net exports of oilseeds and vegetable oils are expected to triple by 2050 (global agriculture towards 2050). Like with other industries, the agriculture sector has also experienced changes through the different phases of the Industrial Revolution. The $1^{\text {st }}$ Industrial Revolution (IR) was the beginning of automation whereby steam and water were used to mechanise production. This was then followed by the use of electrical energy in the $2^{\text {nd }}$ IR for mass production. Next came the $3^{\text {rd }}$ where automation of production utilises electronic and information technology systems. This is where most developing countries including Malaysia is currently at. As Malaysia aspires to become a self-sufficient industrialised nation by 2020 it has to continue to evolve. With the onset of the $4^{\text {th }} I R$, the convergence of technologies has resulted in fuzzy boundaries between the physical, biological and digital domains. Leading towards more innovative and highly likely disruptive technologies that can be incorporated at every level of the oil palm industry from upstream to midstream and all the way to downstream processes.

\section{Upstream Applications}

Taking into consideration the three-pronged strategy that is fully embedded in the Malaysian Palm Oil Board (MPOB)'s charter, that is in creating value towards a high-income nation through sustainable development, we are already witnessing the impact these technologies have on the industry. Developing improved planting materials (through conventional breeding, tissue culture and genetic engineering) has been at the core of MPOB's research and its importance have grown with stagnant yields, land scarcity, labour shortage and climate change threatening the industry. In recent years, disruptive technologies have been driving innovations in all sectors, and agriculture has been in the forefront of these changes (Hall and Martin, 2005). We see developments in technology, biology and data science directing higher production with lesser input of resources as 
we move towards precision agriculture for a more sustainable future (Fess et al., 2011). In the last few decades, the oil palm industry has experienced a merger of traditional sciences with new advances. Conventional breeding in combination with genetics and big data methodologies such as Marker Assisted Breeding are impacting the industry through the development of new planting materials with desirable agronomic traits (Kulwal et al., 2011; Ong-Abdullah et al., 2012). With the lowering cost of sequencing, there has been a rapid growth in the generation of genome information which is supported by improved data analytics. These advancements have brought on new methodologies that are employed in developing improved varieties in breeding such as genotype-by-sequencing (GBS) and genomics selection (Tester and Langridge, 2010). Robust algorithms developed have also opened the floodgates for more re-sequencing of agricultural crops in order to discriminate allelic variation (Furbank and Tester, 2011). The oil palm industry is already witnessing the impact of modern genomicsbased technologies where genes influencing three important agricultural traits in oil palm have been identified (Singh et al., 2013; 2014; Ong-Abdullah et al., 2015). The discoveries have been translated into practical application with the development of the first ever series of diagnostic assays to improve the efficiency of oil palm breeding and tissue culture (Low et al., 2016; Ong-Abdullah et al., 2016).

Production of industrial oils via genetic engineering of the palm adds an extra dimension to the conventional and traditional exploitation of palm oil. Focus of the genetic engineering programme at MPOB is to produce high oleic acid palm oil for industrial application (Parveez et al., 2015). The full complement of genes, promoters and constructs to achieve this are already in place. The successful production of the first transgenic oil palm with BASTA resistance genes indicates an important milestone for the utilisation of the technology to further diversify the application of palm oil. Additionally, the development of microinjection related techniques for genetic modification of oil palm is also an important strategy to circumvent issues related to genetically modified crops (Masani et al., 2014). More recently, a novel genome editing tool known as the Clustered Regularly Interspaced Short Palindromic Repeats Associated Cas9 / sgRNA (CRISPR/Cas9) system which is considered a game changing technology, is set to provide breeders with the flexibility of introducing beneficial traits into the genome (Khatodia et al., 2016).

Development of the diagnostic assays combined with high throughput technologies have also made it possible for large scale screening to ensure only quality planting materials end up in the fields. The use of sensors and GPS-enabled machinery are key elements for precision practices for the industry (Zhang et al., 2002). In this context, the area of phenomics is gaining ground. Traditionally, due to cost and it being a laborious exercise, field phenotyping generally relies on very limited measurements of yield, with some having only single yield data (Furbank and Tester, 2011). This is highly erroneous as yield itself is one of the most poorly inherited traits in breeding. The bottlenecks in field phenotyping sparked intense research in this area which led to the development of combining novel technologies such as non-invasive imaging, spectroscopy, image analysis, robotics and highperformance computing.

A move towards improved automation and mechanisation is also a necessity in modern plantations operations as labour is becoming scarce and a serious concern in the industry. There is no denying that oil palm is lagging behind annual crops in terms of automation as the architecture and terrain where the crop is planted make full mechanisation a challenging task. However, active R\&D efforts have led to some level of mechanisation in the industry although admittedly the efforts have to be enhanced in this direction to reduce the industries dependency on foreign labour. Implementing mechanisation has to be an inclusive package where apart from developing appropriate tools, the workforce has to be trained and equipped with the skills to truly reap the full benefits of mechanisation. In addition to that, by incorporating training of human resource to handle the tools, worker productivity can be enhanced whilst minimising dependency on foreign labour. Tailoring planting materials to future needs such as palms with altered physical architecture such as low stem height and with long stalk would surely facilitate mechanisation practices (Davidson, 1993).

Agriculture is extremely sensitive to changes in climate. The oil palm industry saw the effects of climate change in 2016 with the El Nino phenomenon, which resulted in crude palm oil production declining by $13.2 \%$ compared to 2015 (MPOB, 2017a). Breeding oil palm for adaption to climate change as such, will be an important goal moving forward. Climate change will likely influence soil properties which in turn may have an effect on nutrient up take by the palms and thus the final yield realised (Rival, 2017). The predicted increase in temperature in the future will not only reduce crop yields but also increase risks of diseases and pests (Ceccarelli et al., 2010). Therefore, a comprehensive Integrated Pest Management System (IPM), is priority in controlling pests and diseases such as Ganoderma, Rhinoceros beetles and leaf eating caterpillars, and to be vigilant of potential new threats. Ganoderma continues to be the main focus and deciphering the molecular basis for the infection to develop planting materials resistant to the fungi is the long-term strategy. In the name 
of sustainability, the low-input farming approach is being pursued which will minimise the impact of synthetic chemical fertilisers and pesticides on the environment and food chain (Fess et al., 2011; Leifeld, 2013).

Ultimately, we foresee that the amalgamation of big data from biology and environment, advances in imaging, breeding and predictive algorithms would be the driver in ensuring a sustainable food production for the future.

\section{Midstream Applications}

MPOB aspires to lead the way in this sector through the implementation of a Green Palm Oil Mill and a bio-refinery plant. Renewable energy has been touted as the fifth fuel after gas, oil, coal and hydro. With the nation's dependency on these finite sources for electricity, utilisation of renewable alternatives, such as biomass, biogas, municipal wastes, solar and wind have been given special emphasis under the National Energy Policy. The oil palm especially has an abundant biomass resource for use in power generation (Ooi, 2012) and the use of trapped biogas from the anaerobic effluent ponds will help mitigate greenhouse gas (GHG) emissions (Langeveld et al., 2016).

Refining and fractionation of the future will be taking advantage of the digital technology advancement and producing niche palm oil products such as cold stable olein fraction (Kinney and Knowlto,1998), fully saturate stearin fraction and very sharp melting mid fraction. Designer solid fat fractions (Sonwai et al., 2017) will soon become a commonly available ingredient in the market in the near future.

\section{Downstream Applications}

The oleochemical industry, a segment under chemical industry scope, contributes to almost every manufactured product. Oleochemicals, chemicals derived from vegetable oils and animal fats are used directly or ultimately transformed into intermediate materials and subsequently formulated into products (Salimon et al., 2012; UK Essays, 2013). Thus, the global oleochemical industry serves as the back bone of many end-market industries such as agriculture, automotive, construction, household and consumer products. The $4^{\text {th }}$ IR is expected to catalyse transformation of oleochemical industries through operation improvement and growth. In the context of operation improvement, technologies are introduced to primarily improve productivity through smart manufacturing and reduce risk through supply chain planning (Wang et al., 2016; Sarkis et al., 2011). On the other hand, in the context of growth, technologies or innovations are generated to build incremental revenue or generate new income streams through R\&D and smart goods and services.

\section{Food Products}

Besides being generally known as the most productive oil bearing crop, the oil palm also produces high quality and versatile oils. These attributes have positioned palm oil as the main ingredient in a wide variety of products both food and non-food. Due to its extensive use and its competitive edge over other vegetable oils, palm oil has had a fair share of bad publicity over issues ranging from health to environment. More recently, the quality and safety of palm oil is once again questioned. There are sometimes unfounded claims that presence of non-essential trace elements in palm oil reduces its nutritional benefits (Olafisoye et al., 2015). The case in point is the recent negative press on the presence of 3-MCPD and glycidyl esters (GE) in palm oil. Although the contaminants are present in almost all vegetable oil crops, palm oil was unfairly singled out. Nevertheless, the oil palm industry is continuously innovating and production processes are being improved to reduce and even eliminate contaminants, although their presence is only at trace levels and any adverse risk to health has not been proven. It is envisaged that high-tech instrumentation and robotics technology with the ability to detect these trace elements and for them to be removed as part of the processing supply chain would help clear doubts of the quality of palm oil. The industry continues to improve and attempts to reiterate the versatility of the palm oil whilst emphasising the fact that palm oil is indeed wholesomely nutritious.

The nutraceutical industry is a multibilliondollar industry and one of the most rapidly growing industries. Phenolics are gaining increasing worldwide importance as one of the most potent antioxidants with multiple health benefits. MPOB developed a novel process for the recovery of valuable antioxidants with potential health food, nutraceutical and pharmaceutical applications from this water-soluble fraction of the oil palm. This invention reduces environmental pollution by decreasing the waste generated while producing valuable antioxidants for human consumption. The oil palm phenolics (OPP) extract recovered through a patented process, is rich in phenolic antioxidants such as polyphenols and phenolic acids as well as water-soluble vitamins and organic acids (Sambanthamurthi et al., 2011). Malaysia alone produces more than 50 million tonnes of aqueous waste annually from palm oil milling and MPOB's discovery of valuable phenolic in this waste stream provides an opportunity to revolutionise the oil palm industry and for Malaysia to be the largest producer of phenolics in the world. 


\section{Smallholdings}

Aside from addressing technological issues, the changing consumer behaviours also requires the industry to morph according to their needs. Standards are set while regulations and policies are put in place to safeguard the welfare of the consumers. As we move towards higher productivity, not only do the big plantation players benefit from this but our farmers or the smallholders are also given the opportunity and are empowered to improve their yields and their livelihood to subsequently move the country's status towards a high-income nation. Forty percent of the Malaysian oil palm industry is represented by smallholdings. This group of oil palm grower is divided into two categories i.e. organised smallholders and independent smallholders. Currently there are about 555000 oil palm smallholders in total and of this, 235000 are independent smallholders. Out of 5.74 million hectares of oil palm area in Malaysia, 1.29 million hectares and 0.93 million hectares are owned by the organised and independent smallholders respectively (MPOB, 2017b). The poor fresh fruit bunch (FFB) yield recorded by the smallholders has been blamed for dragging down the overall national palm oil production. Issues such as unproductive palms, not practising good agriculture practices, uneconomic land holding area and incompetent smallholders has been recognised to cause lower smallholders FFB yield. Majority of these smallholders are also lower income earners due to lower oil palm yield and quality. To sustain Malaysia's oil palm industry, oil palm smallholders will need to change their mindsets and rise to the challenge of revolutionising farm management. Organising independent smallholders into cooperatives is also a way forward for small farmers who can collectively reap the benefit from "economies of scale", where larger land holdings will provide better yields and result in lower cost of production (Davidson, 1993).

\section{THE PLANTATION OF THE FUTURE}

The concept of a digital plantation will soon become a reality as industry players are enthusiastically embracing technologies that are shaping the plantation of the $21^{\text {st }}$ century. The advancements in genomics-based technologies for example has trail blazed the industry in terms of facilitating the production of new and improved breeding lines. MPOB's genomics-based diagnostic assays and Sime Darby's genome select palms are excellent examples. Similarly, the downstream sectors, especially expansion of the oleochemical industries, Malaysia's biofuel policies and nutritional research on palm oil augurs well for the growth of the industry as a whole. An oil palm industry that meets universal standards of sustainability will be the cornerstone in ensuring that country achieves this objective. Malaysia in fact led the initiative in this direction, when it became the first country to produce and export certified and sustainable palm oil in 2008. Malaysia's commitment is unwavering, as demonstrated by the active participation of a large number of oil palm companies in RSPO and the development of MSPO standards. A further pledge that all palm oil and its products produced in Malaysia will come from sustainable sources and practices by 1 January 2020, cements Malaysia's commitment to responsible farming practices. These approaches resonate with the government's aspirations in working towards 2050 by when Malaysia will be transformed into a developed nation, that is amongst the top countries in the world in economic development, citizen well-being and innovation. There is still lots to be done from now till then as suitable infrastructure needs to be embedded into the system and the right technologies adopted and adapted to the current frame. We believe with these transformative technologies the oil palm industry will continue to thrive to ensure that it remains viable and sustainable (Figure 1).

\section{ACKNOWLEDGEMENT}

The authors would like to thank all from the different divisions at MPOB for their contribution to this article.

\section{REFERENCES}

BASIRON, Y (2007). Palm oil production through sustainable plantations European J. Lipid Science Technology, 109: 289-295.

BEIRNAERT, A and VANDERWEYEN, R (1941). Contribution a l'etude genetique et biometrique des varietes d'Elaeis guineensis Jacq. (Publication de l'INEAC, Serie Science 27). Institut National pour l'Etude Agronomique du Congo Belge, Bruxelles.

CECCARELLI, S; GRANDO, S; MAATOUGUI, M; MICHAEL, M; SLASH, M; HAGHPARAST, R; RAHMANIAN, M; TAHERI, A; AL-YASSIN, A; BENBELKACEM, A; LABDI MIMOUN, $\mathrm{H}$ and NACHIT, M (2010). Climate change and agriculture paper. Plant breeding and climate changes. J. Agricultural Science, 148: 627-637.

DAVIDSON, L (1993). Management for efficient costeffective and productive oil palm plantations. Proc. of the 1991 PORIM International Palm Oil Conference - Agriculture (Basiron, Y et al., eds.). MPOB, Bangi. p. 153-167. 


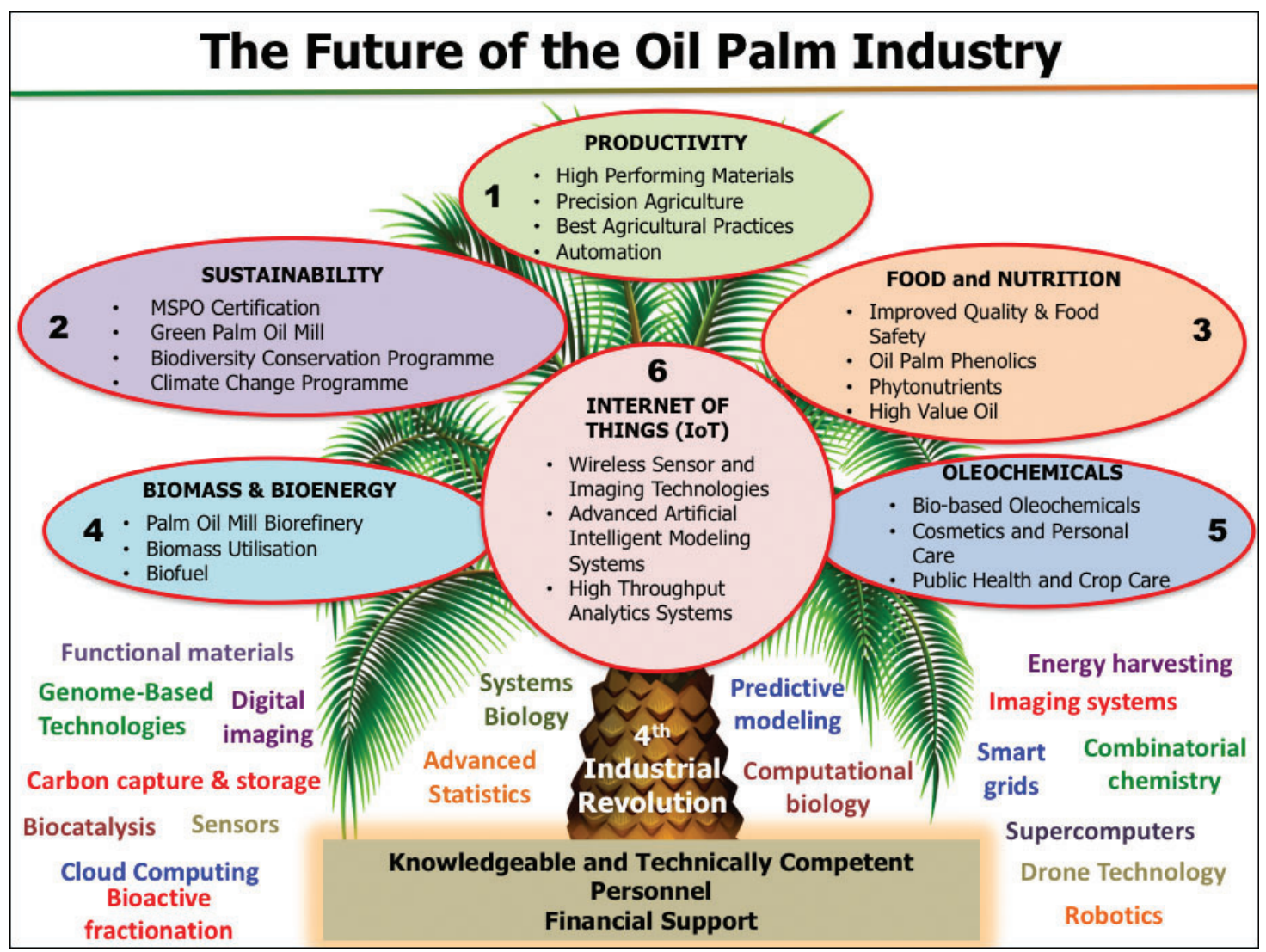

Figure 1. Achieving national targets through the adoption of transformative technologies.

DURAND-GASSELIN, T; DE FRANQUEVILLE, H; BRETON, F; AMBLARD, P; JACQUEMARD, J C; SYAHPUTRA, I; COCHARD, B; LOUISE, C and NOUY, B (2011). Breeding for sustainable palm oil. International Seminar on Breeding for Sustainability in Oil Palm. Kuala Lumpur, Malaysia. p. 155-170.

DURAND-GASSELIN, T; TURNBULL, N; DE FRANQUEVILLE, H; BRETON, F; SYAHPUTRA, I and COCHARD, B (2015). Findings and advances on Ganoderma in oil palm. XVIII Conferencia International Sobre Palma de Aceite. 22-25 September 2015, Cartagena de Indias, Colombia.

FESS, T L; KOTCON, J B and BENEDITO, V A (2011). Crop breeding for low input agriculture: a sustainable response to feed a growing world population. Sustainability, 3: 1742-1772.

FLOOD, J (2006). A review of Fusarium wilt of oil palm caused by Fusarium oxysporum f. sp. Elaeidis. Phytopathology, 96(6): 660-662.

FURBANK, R T and TESTER, M (2011). Phenomicstechnologies to relieve the phenotyping bottleneck. Trends in Plant Science, 16(12): 635-644.

HALL, J K and MARTIN, M J C (2005). Disruptive technologies, stakeholders and the innovation value-added chain: a framework for evaluating radical technology development. RED Management, 35(3): 273-284.

KHATODIA, S; BHATOTIA, K; PASSRICHA, N; KHURANA, S M P and TUTEJA, N (2016). The CRISPR/Cas Genome-Editing tool: application in improvement of crops. Front. Plant Sci., 7:506. DOI: 10.3389 / fpls.2016.00506.

KINNEY, A J and KNOWLTON, S (1998). Designer oils: the high oleic acid soybean. Genetic Modification in the Food Industry. A Strategy for Food Quality Improvement (Sibel Roller and Susan Harlander eds.). Springer-Science+Business Media, B.V. p. 193-213.

KULWAL, P; THUDI, $\mathrm{M}$ and VARSHNEY, R K (2011). Genomics interventions in crop breeding for sustainable agriculture. Encyclopedia of Sustainability Science and Technology. Springer.

LANGEVELD, J W A; GUISSON, $\mathrm{R}$ and STICHNOTHE, H (2016). Technical report on Mobilising sustainable supply chains-biogas cases. IEA Bioenergy.

LEIFELD, J (2013). Low-input farming: a way towards climate-friendly agriculture? Carbon Management, 4(1): 31-41. 
LOW, E T L; SINGH, R; RAJANAIDU, N; ONG_ ABDULLAH, M; OOI, L C L; LAKEY, N D; SMITH, S W; ORDWAY, J M and SAMBANTHAMURTHI, $R$ (2016). New frontiers for the oil palm industry through genome technology. Planter, 92 (1087): 701710

MASANI, M Y A; NOLL, G A; PARVEEZ, G K A; SAMBANTHAMURTHI, R and PRÜFER, D (2014). Efficient transformation of oil palm protoplasts by PEG-mediated transfection and DNA microinjection. PLoS ONE 9(5): e96831. https:// doi.org/10.1371/ journal.pone.0096831

MPOB (2017a). Review of the Malaysian Oil Palm Industry 2016. MPOB, Bangi.

MPOB (2017b). Malaysian Oil Palm Statistics 2016. $36^{\text {th }}$ Edition. MPOB, Bangi.

MURPHY, D J (2014). The future of oil palm as a major global crop: opportunities and challenges. J. Oil Palm Res. Vol. 26 (1): 1-24.

OLAFISOYE, OB;OGUNTIBEJU, OO and OSIBOTE, O A (2015): trace elements and radionuclides in palm oil, soil, water and leaves from oil palm plantations: a review. Critical Reviews in Food Science and Nutrition, 57(7): 1295-1315.

ONG-ABDULLAH, M; MARIA, M; LOW, E T L; MAIZURA, I and RAJINDER, S (2012). Oil palm genomics. Palm Oil: Production, Processing, Characterization and Uses (Lai, O-M; Tan, C-P and Akoh, C C eds.). AOCS Monograph Series. AOCS Press. p. 59-86.

ONG-ABDULLAH, M; ORDWAY, J M; NAN, J; OOI, S E; AZIZAH, M; KOK, S Y; SARPAN, N; AZIMI, N; TARMIZI, A H, ZAMZURI, I; SAMSUL, K R; RAJANAIDU, N; RAJINDER, S; LOW, E T L; SACHDEVA, M; SMITH, S W; LAKEY, N; MARTIENSSEN, R A and SAMBANTHAMURTHI, $R$ (2016). Tissue culture and epigenetics. The Planter, 92(1087): 741-749.

ONG-ABDULLAH, M; ORDWAY, J M; NAN, J; OOI, S E; KOK, S Y; SARPAN, N; AZIMI, N; TARMIZI, A H, ZAMZURI, I; SAMSUL, K R; FADILA, A M; NOR AZWANI, A B ; MARHALIL, M; NORZIHA, A; ZULKIFLI, Y; MOHD DIN, A; NOOKIAH, R; SINGH, R; LOW, E T L; CHAN, K L; AZIZI, N; SMITH, S W; BACHER, B; BUDIMAN, M A; VAN BRUNT, A; WISCHMEYER, C; BEIL,M; HOGAN, M; LAKEY, N; LIM, C C; ARULANDOO, X; WONG, C K; CHOO, C N; WONG, W C; KWAN, Y Y; SYED ALWEE, S S R; SAMBANTHAMURTHI, $\mathrm{R}$ and MARTIENSSEN, R A (2015). Loss of Karma transposon methylation underlies the mantled somaclonal variant of oil palm. Nature 525: 533 - 537.

OOI, H S (2012). Applying green technology in the palm oil industry. Jurutera. p. 18-24.

ORNELAS, K C (2000). History of palm oil. The Cambridge History of Food (Kiple, K F ed.). Volume 2. Cambridge University Press.

PARVEEZ, G K A; RASID, O A; MASANI, M Y A and SAMBANTHAMURTHI, R (2015). Biotechnology of oil palm: strategies towards manipulation of lipid content and composition. Plant Cell Reports, 34(4): 533-543.

PHALAN, B; GREEN, R E; DICKS, L V; DOTTA, G; FENIUK, C; LAMB, A; STRASSBURG, B B N; WILLIAMS, D R; ZU ERMGASSEN, E K H J and BALMFORD, A (2016). How can higher-yield farming help to spare nature? Mechanisms to link yield increases with conservation. Science, 351(6272): 450-451.

RAJANAIDU, N; MARY, N; ONG, E C and LEE, H $H$ (1986). Sabah Breeding Programme (SBP). Proc. of the International Society of Oil Palm Breeders (ISOPB). 26-27 March 1985, PORIM.

RAO, V; LAW, I H; SHAHARUDDIN, Z and CHIA, C C (1999). Ekona and Avros - A tale of two pisiferas. Proc. of the 1999 PORIM International Palm Oil Congress - Emerging Technologies and Opportunities in the Next Millennium (Darus, A; Chan, $\mathrm{K} \mathrm{W}$ and Sharifah, S R S A eds.). p. 90-102.

RIVAL, A (2017). Breeding oil palm (Elaeis guineensis) for climate change. Oilseeds $\mathcal{E}$ Fats Crops and Lipids (OCL), 24(1): D107.

ROMERO, HM; HERRERA, M; OCHOA, J; AVILA, K; SARRIA, G; MONTOYA, C; GUATAQUIRA, $S$ and AYALA, I (2017). Advancement of technologies in bud rot disease control in Colombia. Proc. of the PIPOC 2017 International Palm Oil Congress - Agriculture, Biotechnology and Sustainability Conference - Treasuring the Past, Charting the Future. 14-16 November 2017, KLCC, Kuala Lumpur. p. 10.

ROSENQUIST, E A (1986). The genetic base of oil palm breeding populations. Proc. of the International Workshop on Oil Palm Germplasm and Utilisation. MPOB, Bangi. p. 27-56.

SALIMON, J; SALIH, N and YOUSIF, E (2012). Industrial development and applications of plant oils and their biobased oleochemicals. Arabian J. Chemistry, 5(2): 135-145. 
SAMBANTHAMURTHI, R; TAN, Y A; SUNDRAM, K; ABEYWARDENA, $\mathrm{M}$; SAMBANDAN, $\mathrm{T}$ G; RHA, C K; SINSKEY, A J; SUBRAMANIAM, K; LEOW, S S; HAYES, K C and BASRI, M W (2011). Oil palm vegetation liquor: a new source of phenolic bioactives. British J. Nutrition, 106 (11): 1655-1663.

SARKIS, J; ZHU, Q and LAI, K H (2011). An organizational theoretic review of green supply chain management literature. Int. J. Production Economics, 130: 1-15.

SHARMA, M and TAN, Y P (1999). Oil palm breeding programme and the performance of DxP planting materials at United Plantations Bhd. Proc. of the Seminar on Sourcing of Oil Palm Planting Materials for Local and Overseas Joint Venture. PORIM, Bangi. p. 118-135.

SINGH, R; LOW, E T L; OOI, L C L; ONGABDULLAH, M; NOOKIAH, R; TING, N C; MARJUNI, M; CHAN, P L; ITHNIN, M; MANAF, M A A; NAGAPPAN, J; CHAN, K L; ROSLI, R; HALIM, M A; AZIZI, N; BUDIMAN, M A; LAKEY, $\mathrm{N}$; BACHER, B; VAN BRUNT, A; WANG, C; HOGAN, M; HE, D; MACDONALD, J D; SMITH, S W; ORDWAY, J M; MARTIENSSEN, R A and SAMBANTHAMURTHI, R (2014). The oil palm VIRESCENS gene controls fruit colour and encodes a R2R3-MYB. Nature Communications. DOI: 10.1038/ ncomms5106.

SINGH, R; LOW, E T L; OOI, L C L; ONGABDULLAH, M; TING, N C; NAGAPPAN, J; NOOKIAH, R; A, MOHD DIN; ROSLI, R; MANAF, M A A; CHAN, K L; HALIM, M A; AZIZI, N;
LAKEY, N; SMITH, S W; BUDIMAN, M A HOGAN, M; BACHER, B; VAN BRUNT, A; WANG, C; ORDWAY, J M; SAMBANTHAMURTHI, R and MARTIENSSEN, R A (2013). The oil palm SHELL gene controls oil yield and encodes a homologue of SEEDSTICK. Nature, 500: 340 - 344.

SONWAI, S; RUNGPRASERTPHOL, $\quad \mathrm{P}_{i}$ NANTIPIPAT, N; TUNGVONGCHAROAN, S and LAIYANGKOON, N (2017). Characterization of coconut oil fractions obtained from solvent fractionation using acetone. J. Oleo Science, 66(9): 951-961.

SYED, R A (1981). Pollinating thrips of oil palm in West Malaysia. The Planter, 52: 62-181.

TESTER, M and LANGRIDGE, P (2010). Breeding technologies to increase crop production in a changing world. Science, 327: 818-822.

UK ESSAYS (2013). The importance and advantages of oleochemical industry environmental sciences essay. [online]. https://www.ukessays.com/ essays / environmental-sciences / the-importanceand-advantages-of-oleochemical-industryenvironmental-sciences-essay.php?cref $=1$

WANG, S; WAN, J; LI, D and ZHANG, C (2016). Implementing smart factory of industrie 4.0: an outlook. International J. Distributed Sensor Networks. Volume 2016, Article ID 3159805. 10 pp.

ZHANG, N; WANG, M and WANG, N (2002). Precision agriculture a worldwide overview. Computers and Electronics in Agriculture, 36: 113-132. 